FABULARIO 


\section{Trazos del sujeto andino en Odi Gonzáles}

Por Adriana Sánchez Gutiérrez ${ }^{1}$

I

Con el desafío de encontrar relaciones literarias entre las comunidades indígenas de los Andes, me encontré con diversos textos literarios en quechua, aimara y mapudungun. Uno de mis primeros contactos fue el poeta Fredy Chikangana, quien en su labor social y literaria recupera la lengua quechua en la comunidad Yanakuna de Colombia, ubicada en el departamento del Huila. Para mi sorpresa, en Colombia existían trazos lingüísticos del quechua en las comunidades indígenas del Sur de Colombia, trazando un legado lejano con el Imperio inca al momento de la conquista española. De hecho, los Yanakunas, nominación considerada para los sirvientes del Inca como los Yanaconas, evidencia una estrecha relación con la extensión máxima hacia el norte del Imperio inca en territorio colombiano. Este hallazgo, según algunos lingüistas, demuestra la influencia oral del quechua en diversas comunidades indígenas de los Andes y por ese mismo recorrido montañoso me encontré con un término que adoptaron estos artistas, quienes en la actualidad se conocen como oralitores.

En un encuentro de literaturas indígenas en México en 1994, este término fue presentado por Elicura Chihuailaf como parte de la interacción oral que guardaban los poetas indígenas con sus comunidades, pues la mayoría de las lenguas aborígenes son expresiones orales que posteriormente tienden a ser interpretadas fonéticamente por los lingüistas hasta llegar a una escritura alfabética, tal como se le conoce hoy en día en las publicaciones bilingües de estos artistas. En ese contexto, me encontré con el oralitor Odi Gonzáles, un quechuahablante nativo que evidencia el mestizaje lingüístico y cultural en sus poemas. Su trabajo más impactante, desde mi perspectiva, es Vír-

1 Doctora en Literatura Comparada por la Universidad de Montreal y Magíster en Literatura por la Pontificia Universidad Javeriana. Actualmente es profesora en la Facultad de Nuevas Artes y Ciencias de la Universidad de Purdue. 
genes urbanas, una interpretación lírica a la propuesta plástica de Ana de Orbegoso. En esta obra desfilan, por las calles de Cuzco, mujeres que llevan consigo siluetas de vírgenes con rostros de mujeres quechuas. El mestizaje de estos personajes alude a la época colonial española, matizando en estas figuras católicas la inserción del rostro indígena en iconografías europeas por más de 500 años. En este evento plástico y performativo, Odi Gonzáles reescribe la tradición religiosa de Santa Rosa de Lima, una de las figuras que despierta más devoción en el Perú:

\section{SANTA ROSA}

Mis carnaciones firmes, profanas. Carnaciones de terneja, de mestiza abundosa, gorda como para pobre

No soy la Magdalena, la Hemorroisa, la Samaritana la Adúltera

No soy la Moreneta, la virgen renegrida por el humo de las velas de los feligreses contumaces

Yo soy Rosa. Florista de 5 esquinas. Portal de flores

Campo de quinua. Madre soltera provinciana. Digo: Lima perecerá, Cusco florecerá

Mi túnica flamea. Mi túnica ciñe mi alzada de potranca. En mis dedos la sortija,

la palma del martirio

En mi espalda-cuna mi wawa no es la Virgen-niña hilando

No el Niño de la Espina. ¿O sí?.

Es el Satuco, la Santusa, el Julico retrato de su padre que patea y clama: teta.

El poema de Gonzáles enuncia lo profano como parte de la realidad mestiza y humana que identifica los pueblos post-incaicos, delata las figuras nominativas del cuerpo virginal para contraponerlo a las personas del común. De esta manera, convierte el devocionario católico en estética decolonial que debate los parámetros europeos heredados por el continente americano. Su lírica deconstruye la identidad mestiza del andino e interpela al lector contraponiendo dos mundos anacrónicos al enunciar Lima y Cuzco como opositores históricos que se ceñían bajo un mismo territorio Inca. Gonzáles es capaz de dar polifonía a imágenes que tradicionalmente son inermes, porque nos enfrenta ante diferentes figuras femeninas que se anteponen a las tradiciones católicas de lo puro y lo correcto.

En ese orden de ideas, los textos de este oralitor impactan y emergen en contextos contemporáneos que sacuden estructuras e ideas 
establecidas del sujeto mestizo-andino como el transmigrante de culturas. De alguna manera rompe con el paradigma de un sujeto migrante que se mueve de un lado a otro, ya que, en este caso, las vírgenes son referentes universales de las acciones conquistadoras de Europa en América, pero en esta oportunidad están allí para debatir y responder con realidades cuzqueñas la realidad de las mujeres indígenas y sus hijos.

En ese proceso de reinterpretación de la identidad andina, es casi imposible pasar por alto el profundo significado histórico que inyecta Gonzáles a sus poemas. Por ese motivo seguí sus trazos hasta contactarlo y recibir otros textos que delatan la experiencia de este oralitor en medio de múltiples recorridos que lo han llevado a enfrentarse y cuestionarse sus orígenes, sus tradiciones e incluso el sentido que tiene ser un andino en medio de la gran manzana de Nueva York:

\author{
Umantuu \\ (Brooklyn, NY 11211) \\ dondequiera que vayas, sirena \\ del arco iris, llamadle \\ con tu tamborcillo tenaz \\ a mi alma que vaga de susto silente, cerril \\ desde su primer corte de cabello \\ atraedle pez-diva \\ con engaños y mimos \\ mostrándole perversa \\ tus rebasantes senos \\ de turbia leche dondequiera que te topes, invisible \\ flor de la niebla \\ arread a mi ánima que huye \\ con su asma y sus ejércitos imaginarios \\ encaminadle ya, silbadora insomne \\ por el jirón de los jilgueros por la senda \\ de los despeñaderos \\ dondequiera que llegues, errante \\ ninfa de los vendavales, \\ comparsa de aire puro conducid a mi alma extraviada \\ traedlo a rastras si no quiere venir \\ a este mi lecho de moribundo.
}

Encerrado y ensimismado, con ansías de salir al encuentro de algo o de alguien, los trazos del sujeto andino en este poema se encuentran enmarcados con otras tonalidades sintácticas que denotan el contexto 'moderno' como espacio que ensordece al hombre en medio 
del ambiente apesadumbrado, por eso su voz se tiñe con discursos señoriales en donde el uso del español se formaliza conservando matices lingüísticos que suspenden el instante del oralitor en una niebla espesa que elimina la visión del caminante. En ese recorrido de la obra de Gonzáles, el lector podrá evidenciar la polifonía y disyuntiva que se tejen en las voces de los nuevos escritores indígenas andinos, porque los oralitores irrumpen en mundos bilingües o trilingües debatiéndose ante una academia que debe dar reconocimiento a nuevas propuestas estéticas que continúan el trazado literario que dejaron mundos oníricos ancestrales para salir a agenciar nuevos discursos y opciones decoloniales que enfrentan una visión abierta a la defensa de la oralidad en las comunidades indígenas contemporáneas. 